\title{
Preparedness and responses for prevention and control of COVID-19:
}

\section{a review}

\author{
Md. Shamim Akhter* \\ Orcid id: 0000-0001-5630-3906
}

Biotechnology and Genetic Engineering Discipline, Khulna University, Bangladesh.

*Correspondence e-mail: shamim11akhter@bge.ku.ac.bd

\begin{abstract}
The most striking and dramatic catastrophe, as on April 2020, is - COVID - 19. Understanding of the COVID-19, the causing agent- the virus and the resultant causalities are still evolving. Till now, there is no specific treatment, no vaccine for the COVID-19. At this stage, what is utmost important now to face the disaster is to put emphasis on the preparedness and responses: research to discover vaccine, antivirals as soon as possible. Till then, it is necessary to put emphasis on infection preventive and control measures like to avoid close contact of infected people showing symptoms of respiratory diseases, hand hygiene and coughing etiquette. To make the infection preventive and control measures a success, the followings are to make success: 'quarantine' 'isolation', 'travel bans', 'cordon sanitaire' and 'social distancing' measures. The tools of modern information technology could help the authority to manage and monitor the preventive measures. Above all, preventive and control measures will not be successful if we fail to make aware the common people about the fatality of the COVID - 19. So, rapid preparedness and responses to COVID-19 are critically essential to face such disaster. Not a single moment is to waste!
\end{abstract}


KEYWORDS: COVID - 19; coronavirus; respiratory syndrome; SARS-CoV; preventive and control measures

\section{INTRODUCTION}

COVID-19 is an acute respiratory tract infection that emerged in late 2019 [1-2]. In Wuhan, Hubei Province of China, a group of pneumonia related cases with unfamiliar origin and cause were reported, as on 31 December, 2019. Since the origin of COVID-19 in late December, 2019 from Wuhan, China till to date, it has spread around 200 countries and has become a health concern worldwide [1-2]. Within a few days, on 9 January 2020, China Centre for Disease Control and Prevention (CDC) declared it as a novel coronavirus, the causative agent of this outbreak, now commonly known as COVID-19. The novel coronavirus phylogenetically belong to the severe acute respiratory syndrome corona virus (SARS-CoV). The virus get entry into the cells in the lungs, and other cells in the respiratory system, leading to the infection of other organs, too; causing total disorderness in the physiological system, causing death. As on 03 April 2020, a total of 1,016,128 cases of COVID-19 were confirmed by more than 180 countries and 200 territories. Of note, the majority of cases were reported from outside China, with a growing majority of these reported from EU/EEA countries and the UK. Few cases were also reported from Asia and Africa regions. In this connection, COVID-19 was declared as a worldwide epidemic by the Director General (DG) of the World Health Organization (WHO), on 11 March 2020. Alarmingly, there are no vaccines available and there is little evidence on the no or little (if any) effectiveness of potential therapeutic agents to fight against COVID-19. The more alarming, in this regard, that no pre-existing immunity prevails in the population against the new corona virus. In other 
words, it can be concluded that each and every individual in the world is supposed to be susceptible to the disease. More dangerously, clinical manifestations of COVID-19 are either asymptomatic (no symptoms) or mildly symptomatic (with symptoms) or severe pneumonia, leading to death. Data claims that $82 \%$ of the infected people will suffer from a mild form of disease; $15 \%$ will develop moderate disease, and 3\% will be severely ill [3]. The risk of the COVID-19 of a community, region or a country is to be measured considering the followings: i. Epidemiologic risk- a history of travel/mobility to or residence in the COVID-19 affected areas. For this, contact surveillance and monitoring are essential; and ii. Clinical symptoms- fever, cough, headache, muscle aches, sore throats, respiratory problems, diarrhea, loss of taste and/or smell, normal or reduced white blood cell and lymphocyte count. Inspection for potential symptoms in daily routine activities and accomplishments is necessary to measure clinical symptoms. But it is noteworthy here that symptoms of COVID-19 are found in patients from two days to two weeks after being exposed to the virus: recent data suggest that average time period of onset of COVID-19 symptoms is 5.1 days [4-6]. Last updated casualties of COVID-19 are very shocking, as of 07:45 UTC on 7 April 2020: A total of 1,363,365 cases are confirmed in more than 180 countries and 200 territories, including five cruise ships of USA. Total 994,376 active cases were reported, out of them total 292,188 individuals were recovered and alarmingly, total 76,420 deaths were reported. The case fatality rate was $5.60 \%[6]$.

Taken together all the factual data, as mentioned above, into consideration; the review aimed to point out the events of preparedness, along with responses to the COVID-19 that are utmost importance to combat against it: reduce and/or try to make zero the risk, associated with COVID-19.

\section{COVID-19: PREPAREDNESS AND RESPONSES TO}




\section{In search for drugs: No vaccination, No antiviral treatment}

Till now, no specific antiviral treatment or vaccine has been recognized to be effective enough against COVID-19. The complicacy in the discovery of the vaccine lies in the fact that 2019-nCoV possesses antigenic divergence [7] but scientists were successful to develop peptide based vaccine taking into account of having novel Cytotoxic T Lymphocyte (CTL) epitopes (RVDFCGKGY) for the prevention of 2019-nCoV: It was successfully used in animal models [8]. Moreover, there is another opportunity of using severe acute respiratory syndrome coronavirus (SARS) associated peptide based vaccine for the prevention of $2019-\mathrm{nCoV}$ as there prevails the similarity in the antigenic sites in both SARS coronavirus and 2019-nCoV. There are differences and similarity in the spike glycoprotein of the SARSCoV strain and 2019-nCoV. Moreover, after the outbreak of COVID-19, currently the spike glycoprotein has drawn the attention of the researchers to discover the therapeutics against COVID-19 as this spike glycoprotein is responsible for: binding to its receptor, neutralization of its antibody, fusion into the membrane and finally entry into the host cell [9] (Fig. 1). So, spike glycoprotein inhibitors could be a very potential alternative therapy to combat with 2019-nCoV. 


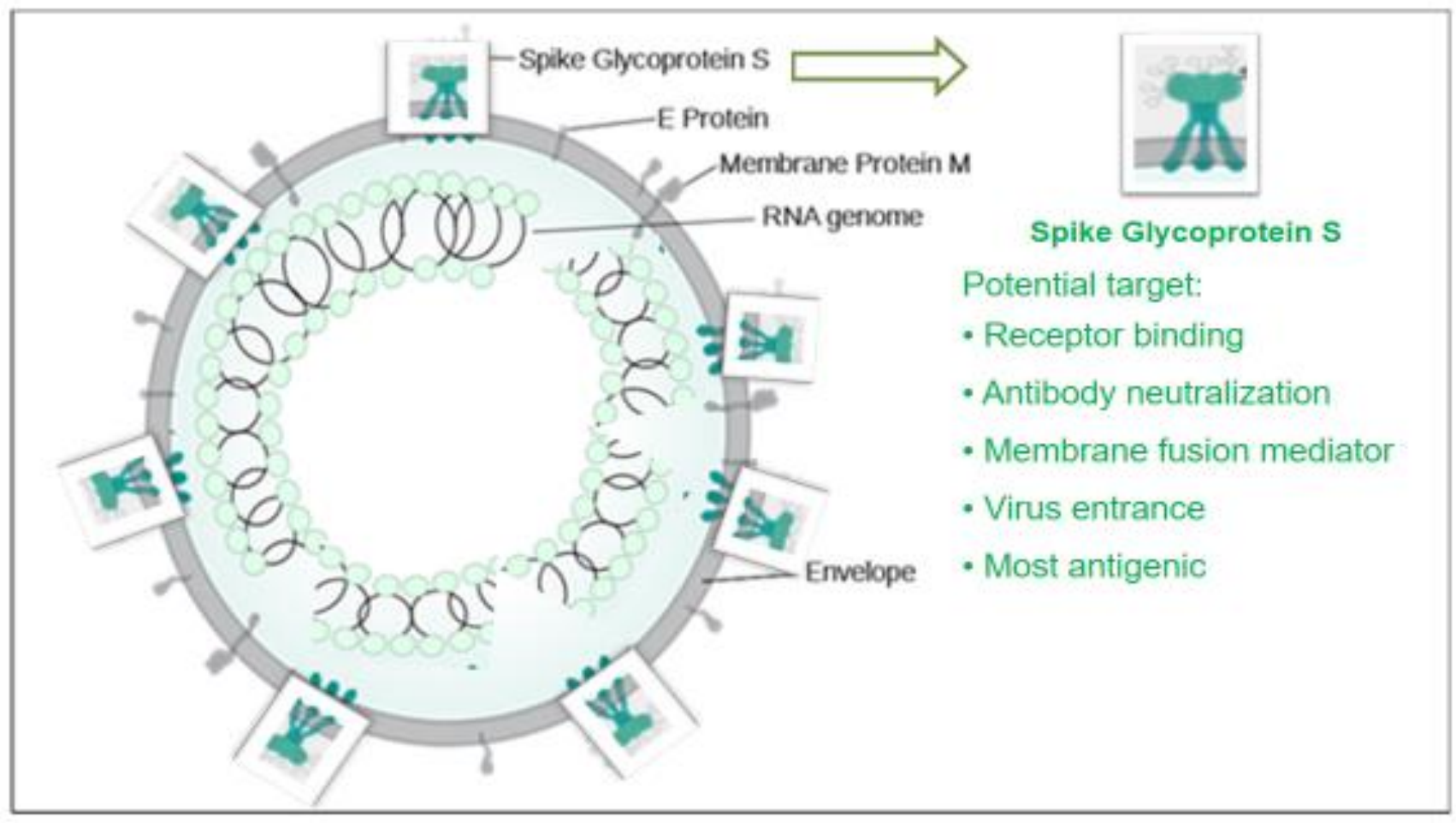

Figure 1: Schematic diagram of the Coronavirus particle. Structural proteins of coronavirus: showing spikes that form a "crown" like structure, hence the name. S, spike protein; M, membrane protein, E, envelope protein; N, nucleocapsid protein (Adapted from [10]).

Table 1: Drugs still being tested to combat COVID-19 [11-17].

\begin{tabular}{|c|c|c|c|}
\hline $\begin{array}{l}\text { Drug, clinical trial } \\
\text { phase: trial number } \\
\text { and } \\
\text { sponsoring institute }\end{array}$ & What it is: existing uses & How does it work & Reference \\
\hline $\begin{array}{l}\text { Chloroquine } \\
\text { Phase IV: } \\
\text { ChiCTR2000029826 } \\
\text { Jingzhou } \quad \text { Central } \\
\text { Hospital }\end{array}$ & $\begin{array}{l}\text { - Synthetic derivative of } \\
\text { quinine } \\
\text { (obtained from bark of } \\
\text { cinchona } \\
\text { tree) } \\
\text { - Used since last } 100 \text { years } \\
\text { - Treat malaria }\end{array}$ & $\begin{array}{l}\text { Slow down virus } \\
\text { entrance into cells, } \\
\text { leading to diminish the } \\
\text { rate of replication }\end{array}$ & {$[11,12,15,16,17]$} \\
\hline $\begin{array}{l}\text { Hydroxychloroquine } \\
\text { Phase IV: } \\
\text { ChiCTR2000029559 }\end{array}$ & $\begin{array}{l}\text { - Derivative of } \\
\text { chloroquine } \\
\text { - Less toxic metabolite of } \\
\text { malaria drug }\end{array}$ & $\begin{array}{l}\text { - } \\
\text { communications } \\
\text { between cells in the } \\
\text { immune system }\end{array}$ & {$[11,12,15,16,17]$} \\
\hline
\end{tabular}




\begin{tabular}{|c|c|c|c|}
\hline $\begin{array}{l}\text { Renmin Hospital of } \\
\text { Wuhan University }\end{array}$ & $\begin{array}{lr}\text { - } & \text { Marketed since } 1950 \\
\text { - Treat } & \text { certain } \\
\text { autoimmune } & \text { disease } \\
\text { (lupus, } & \text { rheumatoid } \\
\text { arthritis) } & \\
\end{array}$ & $\begin{array}{l}\text { - Diminish cytokine } \\
\text { storms }\end{array}$ & \\
\hline $\begin{array}{l}\text { Kaletra } \\
\text { Phase } \\
\text { NCT04321993 } \\
\text { Nova Scotia Health } \\
\text { Authority }\end{array}$ & $\begin{array}{l}\text { - Combination of } 2 \\
\text { antiviral drugs: lopinavir } \\
\text { and ritonavir- } \\
\text { complementary to each } \\
\text { other } \\
\text { - Permitted in the USA } \\
\text { in } 2000 \\
\text { - On the WHO's List of } \\
\text { Essential Medicines } \\
\text { - Treat HIV/AIDS }\end{array}$ & $\begin{array}{l}\text { - Lopinavir } \text { prevents } \\
\text { viral enzymes from } \\
\text { cutting up important } \\
\text { proteins (key to HIV } \\
\text { reproduction) } \\
\text { - Ritonavir increases } \\
\text { concentration rr of } \\
\text { lopinavir in cells }\end{array}$ & {$[11,12,14,15,16]$} \\
\hline $\begin{array}{l}\text { Remdisivir } \\
\text { Phase } \\
\text { NCT04257656 } \\
\text { Capital } \\
\text { University; } \\
\text { Japan } \\
\text { Hospital }\end{array}$ & $\begin{array}{l}\text { - Developed to fight Ebola } \\
\text { but failed to be effective } \\
\text { - Exhibited some positive } \\
\text { effects against corona } \\
\text { virus diseases SARS* and } \\
\text { MERS** }\end{array}$ & $\begin{array}{l}\text { - Block RNA replication } \\
\text { during reproductive } \\
\text { cycle of corona virus }\end{array}$ & {$[11,12,16,17]$} \\
\hline $\begin{array}{l}\text { Losartan } \\
\text { Phase I: NCT04335123 } \\
\text { University of Kansas } \\
\text { Medical Center }\end{array}$ & $\begin{array}{l}\text { - Hypertension drug: } \\
\text { drops blood pressure }\end{array}$ & $\begin{array}{l}\text { - Prevent hormone } \\
\text { angiotensin from binding } \\
\text { to receptors on blood } \\
\text { vessels }\end{array}$ & {$[11,12,15,17]$} \\
\hline $\begin{array}{l}\text { Favipiravir/Avigan } \\
\text { Phase II: } \\
\text { ChiCTR2000029996 } \\
\text { Beijing Chaoyang } \\
\text { Hospital, Capital } \\
\text { Medical University }\end{array}$ & $\begin{array}{l}\text { - Flu drug developed in } \\
\text { Japan } \\
\text { - To treat influenza in } \\
\text { Japan }\end{array}$ & $\begin{array}{l}\text { - Selective inhibition of } \\
\text { viral RNA-dependent } \\
\text { RNA polymerase }\end{array}$ & {$[11,12,13,16,17]$} \\
\hline $\begin{array}{l}\text { Actemra/Tocilizumab } \\
\text { Phase II: } \\
\text { NCT04317092 } \\
\text { National Cancer } \\
\text { Institute, Naples }\end{array}$ & $\begin{array}{l}\text { - Immunosuppressant to } \\
\text { diminish cytokine storms } \\
\text { - Treat rheumatoid } \\
\text { arthritis and juvenile } \\
\text { rheumatoid arthritis }\end{array}$ & $\begin{array}{l}\text { - Blocks a cell receptor } \\
\text { that binds interleukin } 6\end{array}$ & {$[11,12,17]$} \\
\hline
\end{tabular}

*Severe acute respiratory syndrome $\quad * *$ Middle East respiratory syndrome 
The drugs, mentioned above (Table 1), are currently being tested for the treatment and prevention of COVID-19. Still the drugs are not to be used for treatment purposes: it may lead to adverse results, even to death, already reported so [11-17]. In fact, it is one type of approach of research aiming existing drug uses for new therapeutic purposes and/or medical condition [18] like COVID-19, termed as drug repositioning/ drug repurposing/re-profiling/ re-tasking or therapeutic switching [19-20]. What should be emphasized in response to the COVID-19 is to sharing the experiment and clinical data, enhancement of clinical trials, coming forward the volunteers in the clinical trials worldwide [21] for faster legislative and medical approval of the drug. At the same time, it is to be borne in mind that not only drug intake and medication are not enough to combat with fatal diseases like COVID-19 but also maintenance of neat and cleanliness, healthy lifestyle and proper diet intake are to be taken into consideration to improve immunity against deadly diseases [22].

\section{Infection preventive and control (IPC) measures}

To lessen or make zero the risk of being exposed to the virus, infection preventive and control (IPC) procedures are to be monitored like: hand washing with soap and water or disinfection with hand sanitizer where and when necessary, use of face masks (medical masks for doctors, nurses or any other health service providers), use of particulate respirators (certified N95 or FFP2) by doctors, nurses or any other health service providers while treating the suspected and/or infected patients, safely disposal of coughs and sneezes i.e. following appropriate coughing and sneezing etiquette, not to use medical mask in public if there is no respiratory symptoms, avoidance of contact with suspected as well as infected people, and maintenance safe distance, and not to touch eyes, nose, and mouth [23], avoiding close contact with live or dead farming animals or bats or other wild animals [24-25]. To sum up, as there is 
no vaccine or medication reported till to date to completely prevent COVID-19; what could be best approach is to avoid being exposed to the virus through the means as cited above [26]. In this regard, the following point is noteworthy: Not to spread panic among the people but to encourage them to abide by the suggested guidelines. Sometimes, exaggerated information in social and other media spread panic very rapidly, for example, H1N1 influenza in 1976, 2006, and 2009; Ebola spreading in the United States in 2014 [27-28]. And above all, adaptation policies are to be implemented both the short term and long term basis at the community, regional, national levels and worldwide to minimize and/or diminish the impact of the outbreak [29].

For complete or partial prevention, apart from vaccine or inhibitor therapeutics (as noted above), the following initiatives are to be taken like identification and follow-up of contacts, case isolation, environmental disinfection, and use of personal protective equipment (PPE), specially for healthcare professionals [30]. The Centers for Disease Control and Prevention (CDC) outlines PPE that include respirator or facemask, gown, medical gloves, eye protection [31-36]. In case of insufficient stocks of PPE, priorities are to be determined for use [3].

People are supposed to go through the sufferings of distress, monotony and wearisomeness due quarantine, travel restrictions, unnecessary panic, exaggerated rumor, side effects of treatment, and above all, the fear to get the infection [37-38]. Psychological crisis interventions are also, additionally, recommended for the patients, even for doctors, nurses and other service providers [39-40]. Increasing public awareness regarding all the infection preventive and control (IPC) measures, as mentioned above, is of paramount importance, to minimize the causalities due to the catastrophe, COVID-19. 


\section{Confirmatory tests}

To make sure the confirmatory pathogenic evidence, either real-time reverse-transcription -polymerase chain reaction (RT-PCR) test (for nucleic acid in respiratory, blood samples, etc.) [41-42] or viral gene sequencing (showing highly homogeneity to the known 2019-nCoV in respiratory or blood samples) are to be conducted. As COVID-19 patients, in some cases, show no fever and other abnormalities; it is complicated and tough to take the decision to go for the confirmatory tests by the medical physicians and doctors, keeping in mind that there is scarcity of kits and space in hospitals. In such cases, an alternative to be thought to make the required facilities available outside the hospital for treatment and diagnosis, as well, providing biosafety levels and other prerequisites [5]. It is fact that there are shortages for laboratory testing for COVID-19, even in developed countries like USA, EU; in that case, there should be optimization of the scientific uses of existing lab facilities and resources at a rational approach $[3,43]$. Logistic supports, facilities and skilled manpower with enough personal protection equipment (PPE) to conduct RT-PCR and viral gene sequencing are burning needs, especially in low-income countries, affected with COVID-19.

\section{'Old tools'}

Another legal weapon to face the challenge of COVID-19 is to impose 'quarantine' (separation of persons (or communities) who have been exposed to an infectious disease), 'isolation' (separation of persons who are known to be infected), 'travel bans', 'cordon sanitaire' (a line around a quarantined area guarded to prevent the spread of a disease by restricting passage into or out of the area) and 'social distancing' measures. Though some scientists criticize about these measures terming as 'old tools' and 'being not entirely successful for highly transmissible diseases' [44-47]. To enforce 'quarantine', 
'isolation', 'travel bans', and 'social distancing' is troublesome for the authority because the transmission of COVID-19 infection from human to human or from any other source to human could be either without any symptoms or with very mild symptomatic cases taking 5 to 14 days of incubation. In fact, it is very significant to measure the severity and the rate of transmission of the infection: mild, very mild and without any symptom cases, prior to take the decision to impose lockdown and/or curfew to make 'quarantine', 'isolation', 'travel bans', and 'social distancing' a successful. The nature of infection- mild, very mild and asymptomatic of COVID-19 infection determine the containment and restraint strategies formulation. [48-50]. In addition, temporary and emergency hospitals could be established, obviously apart from locality, to provide treatment and take care in pandemic like COVID19 [51]. List of quarantinable diseases is declared by the legal authorities of Centers for Disease Control and Prevention (CDC): cholera, diphtheria, infectious tuberculosis, plague, smallpox, yellow fever, viral hemorrhagic fevers, severe acute respiratory syndrome, influenza that can cause a pandemic; COVID19 belongs to the quarantinable diseases as it has severe acute respiratory syndrome [52].

\section{'New tools': Information technology}

As an alternate of 'old tools' (as illustrated above), the tools of the information technology can be implied to fight against disasters like COVID-19. For example, 'mobile apps' using surveillance data can detect close contacts and/or public gathering of mobile users, leading to the threat detection of infection of a COVID-19 prone area. The 'mobile apps' can suggest the 'mobile user' to go for 'self quarantine'. Even it can sent message to the local authority regarding every update of the COVID-19 infection of a specific area [53-54]. 
Very recently as on March 2020, in South Korea, Taiwan, and Singapore, Estonia, German, Italy, Israel and some other countries: tools like mobile phone tracking, facial recognition technology, telephone helplines and artificial intelligence were used to track COVID-19 infected people and people whom they contacted via big data analytics on cellphone data, thus lockdown, curfew, 'quarantine', 'isolation', 'travel bans', and 'social distancing' were imposed where and when necessary among the infected citizens [55-59]. In a word, information technology tools can make national surveillance systems quite effective for rapid detection of new cases, leading to the assessment of a community transmission. Thus a total tactical methodology based on the application of information technology tools would lessen the work loads and pressure on the total healthcare system and health service providers, as well. So, to dare to overthrow COVID-19, both 'old' and 'new' tools are to be applied simultaneously; they are to complement each other.

\section{Exploit ambassadorial liaison}

In addition to the technical preventive measures, ambassadorial and diplomatic steps are also very important: Data sharing on such diseases worldwide, International industries and researcher collaboration to discover therapeutics, donation and other helps and supports from rich countries to low and middle-income countries (LMICs), and most importantly, strengthen health care system worldwide investing more in disease surveillance and related research rather than investment in purchasing and/or preparation of arms and weapons [60-62].

\section{Last but not the least: the efficient management for suspected and non-suspected patients}

After the measurement of the epidemiologic risk (as described in introduction section): a history of travel/mobility to or residence in the COVID-19 affected areas and clinical symptoms: fever, respiratory 
problems, diarrhea, and normal or reduced white blood cell and lymphocyte count; the individuals are to be screened for rapid sanatorium admission or for home testing for COVID-19 and subsequent impose of quarantine, isolation, travel bans, cordon sanitaire and social distancing (as described in the 'old tools' section).

For non-suspected individuals, counselling on infection preventive and control (IPC) measures: hand washing with soap and water, disinfection with hand sanitizer, following appropriate coughing and sneezing etiquette, avoidance of contact with suspected as well as infected people, and maintenance safe distance, and not to touch eyes, nose, and mouth, use of face masks (where and when necessary).

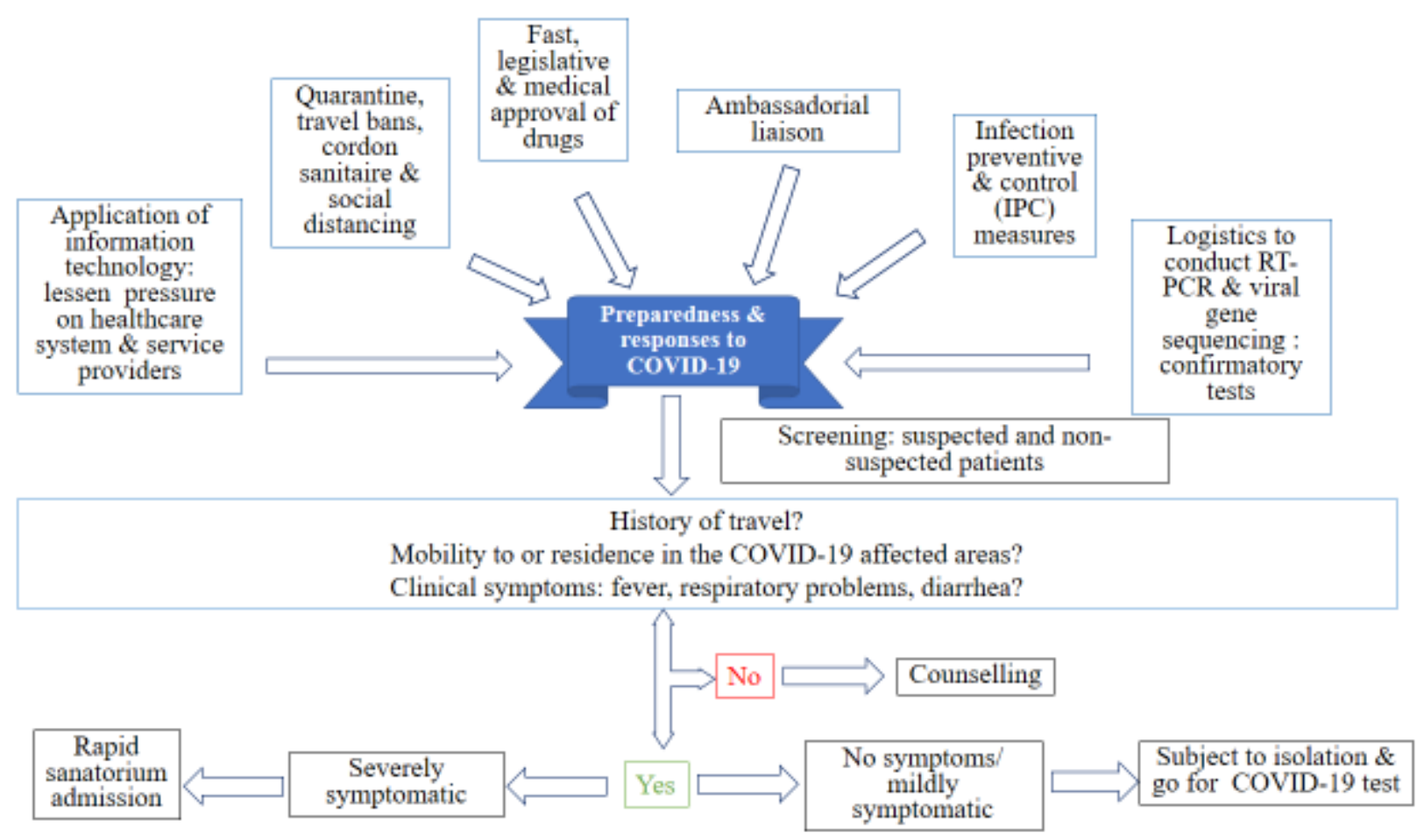

Figure 2: Schematic diagram illustrating the preparedness and responses to COVID-19.

\section{CONCLUSION}

As of on April, 2020; vaccine against COVID-19 is not expected to become available for application to the common people until 2021 at the earliest, emphasis is to be given on preventive and control 
measures to reduce and/or try to make zero the chances of infection. From the worldwide scenario of the outbreak of COVID-19, it is obvious that the present health care system is not enough to combat such fatal outbreak, suggesting more allocation for health care system and research, as well. It is predicted as per current literature and information provided by WHO, CDC and ECDC that COVID-19 is yet to grow and the epidemic is yet to continue; so the responses and preparedness for COVID-19 will be challenged in the concerned areas and worldwide, as well. There is no alternative rather than to take initiatives to gear up the preparedness and responses to COVID-19. To sum up: vaccine and other effective drugs to treat COVID-19 are to be made available for common people worldwide as soon as possible. And following the prescribed preventive and control guidance rigidly as instructed by the appropriate authority, COVID-19 is to be contained to prevent further spread. The sooner, the better. There is no time left to waste! The battle must be won!

\section{ACKNOWLEDGEMENT}

Author acknowledge and thank his respective institute: Khulna University.

\section{FUNDING}

This review is written, analyzed and designed by its author and required no substantial funding to be stated.

\section{REFERENCES}

[1] Gorbalenya AE, Susan CB, Ralph SB, Raoul JG, Christian D, Anastasia AG et al. Severe acute respiratory syndrome-related coronavirus: The species and its viruses - a statement of the Coronavirus Study Group. bioRxiv, 2020; https://doi.org/10.1101/2020.02.07.937862 (2020) 
[2] Zhu N, Zhang D, Wang W, Xingwang L, Bo Y, Jingdong S. et al. A novel coronavirus from patients with pneumonia in China, 2019. N Engl J Med. 2020; 382:727-33.

[3] European Centre for Disease Prevention and Control (ECDC) (2020). Novel coronavirus disease 2019 (COVID-19) pandemic: increased transmission in the EU/EEA and the UK-sixth update -12 March 2020.

[4] WHO (2020). Novel coronavirus (2019-nCoV): Situation report - 5, 25 January 2020. Geneva. https://www .who .int/ docs/ default - source/ coronaviruse/ situation - reports/ 20200125 - sitrep - 5 2019 - ncov .pdf.

[5] General Office of National Health Committee. Office of State Administration of Traditional Chinese Medicine (2020). Notice on the issuance of a programme for the diagnosis and treatment of novel coronavirus (2019-nCoV) infected pneumonia (Trial Version 4). http://bgs.satcm.gov.cn/ zhengcewenjian/2020-01-28/12576.html.

[6] Johns Hopkins CSSE (2020). Coronavirus COVID-19 Global Cases by the Center for Systems Science and Engineering (CSSE) at Johns Hopkins University (JHU)". ArcGIS. "Coronavirus Update (Live) - Worldometer". www.worldometers.info. Retrieved on 3 April 2020.

[7] Kumar S, Vimal KM, Anil KP, Madan LBB, Shailendra KS. Structural, glycosylation and antigenic variation between 2019 novel coronavirus (2019-nCoV) and SARS coronavirus (SARS-CoV). Virus Dis. 2020; 31(1):13-21 https://doi.org/10.1007/s13337-020-00571-5.

[8] Choy WY, Lin SG, Chan PK, Tam JS, Lo YM, Chu IM, et al. Synthetic peptide studies on the severe acute respiratory syndrome (SARS) coronavirus spike glycoprotein: perspective for SARS vaccine development. Clin Chem. 2004; 50(6):1036-42.

[9] Oostra M, de Haan CA, Rottier PJ. The 29-nucleotide deletion present in human but not in animal severe acute respiratory syndrome Coronaviruses disrupts the functional expression of open reading frame 8. J Virol. 2007; 81(24):13876-88. 
[10] Coronavirus disease 2019 (2020). https://en.wikipedia.org/wiki/Coronavirus_disease_2019. Retrieved on 18 April, 2020.

[11] Science Nature Page (2020). Coronavirus: 7 drugs that are being explored to treat COVID-19. https://www.facebook.com/watch/?v=1670726906407826. Retrieved on 01 April, 2020.

[12] Science Nature Page (2020). Coronavirus: 7 drugs that are being explored to treat COVID-19. ScienceNaturePage/videos/1670726906407826/UzpfSTEwMDAxMDQ0ODEwOTg0NTpWSzozOT UxMzYwMzMxNTQxNjA2/. Retrieved on 01 April, 2020.

[13] Jin Z, Smith LK, Rajwanshi VK, Kim B, Deval J. The ambiguous base-pairing and high substrate efficiency of T-705 (Favipiravir) Ribofuranosyl 5'-triphosphate towards influenza A virus polymerase PLOS One. 2013; $8 \quad$ (7): e68347. Bibcode: 2013PLoSOne...868347J. doi:10.1371/journal.pone.0068347. PMC 3707847. PMID 23874596.

[14] The American Society of Health-System Pharmacists (2020). "Lopinavir and Ritonavir". https://medlineplus.gov/druginfo/meds/a602015.html. Retrieved on 01 April, 2020.

[15] WHO (2019). World Health Organization model list of essential medicines: 21st list 2019. Geneva: World Health Organization. hdl: 10665/325771. WHO/MVP/EMP/IAU/2019.06. License: CC BY-NCSA 3.0 IGO.

[16] Selina K, Winnie P (2020). First up for COVID-19: nearly 30 clinical readouts before end of April. BioCentury Inc. https://www.biocentury.com/article/304658/nearly-30-trials-for-covid-19-could-startto-yield-data-in-the-next-couple-of-months.

[17] U.S. National Library of Medicine (2020). Information for clinicians on therapeutic options for COVID-19 patients. US Centers for Disease Control and Prevention. 2020; https://clinicaltrials.gov/ct2/results?cond=COVID-19. Retrieved on 8 April 2020. 
[18] NIH (2020). National Center for Advancing Translational Sciences (NCATS), Repurposing Drugs. https://ncats.nih.gov/preclinical/repurpose. Retrieved on 26 March 2020.

[19] Charlotte H. Coronavirus puts drug repurposing on the fast track. Nature Biotechnology. 2020; doi: 10.1038/d41587-020-00003-1. PMID 32205870.

[20] Sleigh SH, Barton CL. Repurposing Strategies for Therapeutics. Pharm. Med. 2010; 24 (3): 151159. doi: 10.1007/BF03256811

[21] WHO (2020). Nebehay S, Kelland K, Liu R. WHO: 'no known effective' treatments for new coronavirus. Thomson Reuters. 2020. https://www.reuters.com/article/us-china-health-treatments-whoidUSKBN1ZZ1M6. [22] Wang L, Wang Y, Ye D. Liu Q. A review of the 2019 Novel Coronavirus (COVID-19) based on current evidence. Int J Antimicrob Agents. 2020; 105948. doi:10.1016/j.ijantimicag.2020.105948.

[23] CDC (2020). 2019 Novel coronavirus, Wuhan, China. 2020. https://www.cdc.gov/ coronavirus/2019-nCoV/summary.html. Retrieved on 1 April 2020.

[24] WHO (2020). Infection prevention and control during health care when novel coronavirus (nCoV) infection is suspected. 2020. https:// www.who.int/publications-detail/infection-prevention-and-controlduringhealth-care-when-novel-coronavirus-(ncov)-infection-is-suspected-20200125. Retrieved on 26 March 2020.

[25] WHO (2020). WHO advice for international travel and trade in relation to the outbreak of pneumonia caused by a new coronavirus in China. 2020. https://www.who.int/ith/20200901_outbreak_of_Pneumonia_caused_by_a_new_coronavirus_in_C/en/ . Retrieved on 23 Jan 2020.

[26] Ou F, Wu H, Yang Y, Tan W, Zhang J, Gu J. Countermeasures for rapid spread of new coronavirus pneumonia in Wuhan. Chin General Pract Nurs. 2020. 
http://kns.cnki.net/kcms/detail/14.1349.R.20200131.1319.002.html. Peltz G. Computational Genetics and Genomics: Tools for Understanding Disease. Humana Press: Totowa, NJ, USA, 2005.

[27] Farmer PE. Diary: Ebola. London Review of Books. London, 36: 38-9, 2014.

[28] National Health Commission of People's Republic of China. (2020). Guidelines for public protection against novel coronavirus infection. http://www.nhc. gov.cn/jkj/s7915/202001/bc661e49b5bc487dba182f5c49ac445b.shtml. Retrieved on 31 March 2020.

[29] Adhikari SP, Sha Meng, Yu-Ju Wu, Yu-Ping Mao, Rui-Xue Ye, Qing-Zhi Wang, Chang Sun, Sean Sylvia, Scott Rozelle, Hein Raat and Huan Zhou. Epidemiology, causes, clinical manifestation and diagnosis, prevention and control of coronavirus disease (COVID-19) during the early outbreak period: a scoping review; Infect Dis Poverty. 2020; 9: 29. https://doi.org/10.1186/s40249-020-00646-X

[30] Wei Q, Ren Z. Disinfection measures for pneumonia foci infected by novel coronavirus in 2019. Chin J Disinfect. 2020; 37:59-62.

[31] NIOSH-CDC (2018). Wayback Machine. Filtering out Confusion: Frequently Asked Questions about Respiratory Protection, User Seal Check Archived 16 August 2019 at the Wayback Machine.

[32] NIOSH-CDC (2020). Wayback Machine. Proper N95 Respirator Use for Respiratory Protection Preparedness Archived 27 March 2020 at the Wayback Machine.

[33] CDC (2020). Coronavirus Disease 2019 (COVID-19). Interim guidelines for collecting, handling, and testing clinical specimens from persons for coronavirus disease 2019 (COVID-19). https://www.cdc.gov/coronavirus/2019-ncov/lab/guidelines-clinical-specimens.html. Retrieved on 31 March 2020.

[34] CDC (2020). Coronavirus Disease 2019 (COVID-19). https://www.cdc.gov/coronavirus/2019ncov/faq.html\#How-to-Protect-Yourself. Retrieved on 28 March 2020.

[35] CDC (2020). Strategies for Optimizing the Supply of Eye Protection. https://www.cdc.gov/coronavirus/2019-ncov/hcp/faq.html. Retrieved on 29 March 2020. 
[36] CDC (2020). Interim Infection Prevention and Control Recommendations for Patients with Suspected or Confirmed Coronavirus Disease 2019 (COVID-19) in Healthcare Settings. https://www.cdc.gov/coronavirus/2019-ncov/faq.html\#Healthcare-Professionals-and-Health-

Departments. Retrieved on 28 March 2020.

[37] Xiang YT, Yang Y, Li W, Zhang L, Zhang Q, Cheung T, et al. Timely mental health care for the 2019 novel coronavirus outbreak is urgently needed. Lancet Psychiat. 2020; 7 (3): 228-29. doi:10.1016/S2215-0366(20)30046-8. PMID 32032543.

[38] Kang L, Li Y, Hu S, Chen M, Yang C, Yang BX, et al. The mental health of medical workers in Wuhan, China dealing with the 2019 novel coronavirus. Lancet Psychiat. 2020; 7 (3): e14. doi:10.1016/S2215-0366(20)30047-X. PMID 32035030.

[39] Xu M, Zhang Y. Investigation on the psychological status of the first batch of clinical first-line support nurses to fight against pneumonia caused by novel coronavirus. Chin Nurs Res. 2020; 34:1-3.

[40] Wang C, Wang X. Prevalence, nosocomial infection and psychological prevention of novel coronavirus infection. Chin General Pract Nurs. 2020; 18: 2-3.

[41] Li L, Ren MJ, Zhang YY, Li WQ, Zhao HY, Liang LC, et al. Lung CT image of a confirmed case of the 2019 novel coronavirus (2019-nCoV) infected pneumonia (With differential diagnosis of the SARS). Yixue Xinzhi. 2020; 30(1):4-6 [Article in China].

[42] WHO (2020). Corman V, Bleicker T, Brünink S, et al. Diagnostic detection of Wuhan coronavirus 2019 by real-time RT-PCR. https://www .who .int/ docs/ default - source/ coronaviruse/ wuhan - virus - assay - v1991527e5122341d99287a1b17c111902 .pdf.

[43] WHO (2020). Global Surveillance for human infection with novel coronavirus (2019-nCoV): Interim guidance [March 11, 2020]. https://www.who.int/publications-detail/global-surveillance-forhuman-infection-with-novel-coronavirus-2019-ncov). 
[44] Gostin LO, Hodge JG Jr. US emergency legal responses to novel coronavirus: balancing public health and civil liberties. 2020; JAMA. doi: 10.1001/jama.2020.2025. PMID: 32053150 (Epub ahead of print).

[45] Parmet WE. Quarantining the law of quarantine: why quarantine law does not reflect contemporary constitutional law. Wake Forest J Law Policy 2018; 9: 1-33.

[46] ACLU (American Civil Liberties Union) (2015). Yale Health Global Justice Partnership. Fear, politics and Ebola: how quarantines hurt the fight against Ebola and violate the Constitution. https://www .aclu .org/ sites/ default/ files/ field_document/ aclu - ebolareport .pdf.

[47] Aledort JE, Lurie N, Wasserman J, Bozzette SA. Non-pharmaceutical public health interventions for pandemic influenza: an evaluation of the evidence base. BMC Public Health 2007; 7: 208.

[48] WHO (2020). Novel Corona Virus (2019-nCoV): situation report - 12. https://www .who .int/ docs/ default - source/ coronaviruse/ situation - reports/ 20200201 - sitrep - 12 - ncov .pdf?sfvrsn=273c5d35_2).

[49] Wu JT, Leung K, Leung GM. Nowcasting and forecasting the potential domestic and international spread of the 2019-nCoV outbreak originating in Wuhan, China: a modelling study. Lancet. 2020; 395: $689-97$.

[50] Imai N, Dorigatti I, Cori A, Riley S, Ferguson NM. Estimating the potential total number of novel Coronavirus cases in Wuhan City, China. Imperial College London, 2020. doi: https://doi.org/10.25561/77150 https://www .imperial .ac .uk/ media/ imperial - college/ medicine/ sph/ ide/ gida - fellowships/ 2019 - nCoV - outbreak - report - 17 - 01 - 2020 .pdf.

[51] American Unofficial Collection of World War I Photographs, 1917 - 1918. National Archives Identifier: 45499327; Photograph 165-WW-269B-19. Influenza Epidemic 1918 - Emergency hospital, Brookline, Massachusetts, to care for influenza cases; Records of the War Department General and Special Staffs, Record Group 165; National Archives at College Park, College Park, MD. 
https://www.docsteach.org/documents/document/emergency-hospital-brookline-massachusettsinfluenza.

[52] CDC (2020). Centers for Disease Control and Prevention. Legal authorities for isolation and quarantine. www.cdc.gov/quarantine/ aboutlawsregulationsquarantineisolation.html. Retrieved on 28 March 2020.

[53] Chen A (2020). China's coronavirus app could have unintended consequences. MIT Tech. Review. https://www.technologyreview.com/2020/02/13/844805/coronavirus-china-app-close-contactsurveillance-covid-19-technology. Retrieved on 7 April 2020.

[54] BBC (2020). 'Close contact' app, China launches coronavirus. BBC News. 11February 2020. https://www.bbc.com/news/technology-51439401. Retrieved on 22 April, 2020.

[55] Manancourt V (2020). Coronavirus tests Europe's resolve on privacy. Politico. https://www.politico.eu/article/coronavirus-tests-europe-resolve-on-privacy-tracking-apps-germanyitaly/. Retrieved on 29 March 2020.

[56] Tidy J (2020). Coronavirus: Israel enables emergency spy powers. BBC News. https://www.bbc.com/news/technology-51930681. Retrieved on 28 March 2020.

[57] Bünte O. Corona-Krise (2020). Deutsche Telekom liefert anonymisierte Handydaten an RKI. Corona crisis: Deutsche Telekom delivers anonymized cell phone data to RKI. Heise Online (in German). https://www.heise.de/newsticker/meldung/Corona-Krise-Deutsche-Telekom-liefertanonymisierte-Handydaten-an-RKI-4685191.html?wt_mc=rss.red.ho.ho.rdf.beitrag.beitrag. Retrieved on 29 March 2020.

[58] Dannewitz, J (2020). Hackathon Germany: \#WirvsVirus. Datenschutzbeauftragter (in German). https://www.datenschutzbeauftragter-info.de/ziel-und-inhalt-dieser-website/. Retrieved on 29 March 2020. 
[59] Whyte A (2020). President makes global call to combat coronavirus via hackathon. ERR. https://news.err.ee/1067171/president-makes-global-call-to-combat-coronavirus-via-hackathon. Retrieved on 23 March 2020.

[60] Gates B. The next epidemic — lessons from Ebola. N Engl J Med. 2015; 372: 13814.

[61] Gates B. Innovation for pandemics. N Engl J Med. 2018; 378: 2057-60.

[62] Frieden TR, Tappero JW, Dowell SF, Hien NT, Guillaume FD, Aceng JR. Safer countries through global health security. Lancet 2014; 383: 764-66. 